\title{
The Total Suspended Matter Concentration Field in the Kerch Strait Based on Optical Observations
}

\author{
P. D. Lomakin, A. I. Chepyzhenko, A. A. Chepyzhenko* \\ Marine Hydrophysical Institute, Russian Academy of Sciences, Sevastopol, Russian Federation \\ *e-mail: annachep87@yandex.ru
}

Based on results of several expeditions, carried out in 2001-2014, ideas about the total suspended matter (TSM) sources were obtained. The main features of the TSM concentration field structure in the Kerch Strait waters were revealed. It was shown, that the natural TSM field is being significantly distorted by anthropogenic impact. The most significant anthropogenic TSM sources include the operating ports on the Kerch Strait and in the Sea of Azov shores, industrial enterprises, sewage collectors, cargo terminals and landfill sites. The spatial scale of their effect was estimated. It was found, that the waters with excess TSM content are also saturated by dissolved organic matter (DOM) of anthropogenic origin. In the Kerch Strait, a frontal section in the TSM concentration field was found. It was revealed that depending on the Strait waters pollution degree the frontal section in the TSM field content cannot always be sufficiently viewed. It changes shape, shifts relative to thermohaline front and sometimes changes the horizontal gradient sign. It is found that the Black and the Sea of Azov waters have qualitatively different signs of total suspended matter vertical stratification. The Sea of Azov waters, unexposed to anthropogenic impact are characterized by non-monotonic TSM distribution. The TSM streams from the Sea of Azov contain the lenses of high TSM content, which alternate with the lenses of low TSM content.

Keywords: total suspended matter, the Kerch Strait.

DOI: 10.22449/1573-160X-2017-6-58-69

(c) 2017, P. D. Lomakin, A. I. Chepyzhenko, A. A. Chepyzhenko*

(C) 2017, Physical Oceanography

Introduction. Total suspended matter (TSM) is an important parameter of the aquatic environment, which from the classical oceanography standpoint has not still been studied so far. The reason is the lack of reliable measuring tools assisting to extract mass information on the TSM concentration in the water areas under consideration. It is the explanation of the insignificant amount of relevant information in modern oceanographic data databases and insufficient knowledge of the TSM fields in the oceans, seas, their separate areas and other waterbodies [1-4].

The first oceanographic research of the TSM content in the Kerch Strait waters concerning its sources are described in [5]. In this work the TSM concentration field structure is briefly described at a qualitative level.

In the present paper, the data on anthropogenic and natural TSM sources in the Kerch Strait, estimated on the basis of a more extensive array of initial data applying the classical oceanography methods, was supplemented. The particular concentration of the studied substance in the uncontaminated waters of the Azov and Black Seas interacting in the strait was determined. Typical features of the TSM field vertical stratification are revealed. For the first time a frontal section in the considered field was identified, due to the Azov and Black Sea waters' interaction.

Initial data and research methods. Mass data on the TSM content in the waters of the Azov and Black Seas appeared as a result of optical methods' for the 
rapid determination of this substance concentration introduction into expeditionary practice. At the end of the last century such measurements were first to be carried out in the selected water samples in laboratory conditions in Marine Hydrophysical Institute (MHI).

Since 2001, similar measurements have been carried out directly in the sea applying the Kondor meter [6]. Additionally to the TSM content fixing channel, the meter is equipped with channels for synchronous determination of dissolved organic matter (DOM) concentration, temperature and salinity. It also includes a portable meter of currents. This device was used in a series of complex expeditions of MHI in the coastal and open waters of the Black and Azov Seas in 2001-2015. As a result, an oceanological database was created that made it possible to get an overview of the natural and anthropogenic sources and structure of the TSM content field in the considered water areas.

Information on the Expeditions to the Kerch Strait Area

\begin{tabular}{|c|c|c|c|}
\hline No. & Date & Organizations+Members & Number of Stations \\
\hline 1 & 22.06 .2001 & MHI + YugNIRO + IBSS & 17 \\
\hline 2 & 30.10 .2001 & MHI + YugNIRO + IBSS & 17 \\
\hline 3 & 20.04.2002 & MHI + YugNIRO + IBSS & 17 \\
\hline 4 & 07.11 .2002 & MHI + YugNIRO + IBSS & 17 \\
\hline 5 & 15.04.2003 & MHI + YugNIRO + IBSS & 19 \\
\hline 6 & 02.08 .2003 & MHI + YugNIRO + IBSS & 20 \\
\hline 7 & 05.05.2005 & MHI + YugNIRO & 36 \\
\hline 8 & 29.02.2008 & MHI & 49 \\
\hline 9 & 24.03.2008 & MHI & 36 \\
\hline 10 & 08-10.04.2008 & MHI & 54 \\
\hline 11 & 23-24.07.2008 & MHI & 62 \\
\hline 12 & 01-03.09.2008 & MHI & 45 \\
\hline 13 & 08.12 .2008 & MHI & 28 \\
\hline 14 & 14-15.04.2009 & MHI & 69 \\
\hline 15 & 25-26.06.2009 & MHI & 70 \\
\hline 16 & 12-13.11.2009 & MHI & 51 \\
\hline 17 & 04-05.12.2009 & MHI & 28 \\
\hline 18 & 14.05.2010 & MHI & 52 \\
\hline 19 & $24-25.07 .2010$ & MHI + YugNIRO & 22 \\
\hline 20 & $11-12.11 .2010$ & MHI & 48 \\
\hline 21 & 17-18.05.2011 & MHI & 53 \\
\hline 22 & $01-02.08 .2011$ & MHI + YugNIRO +VNIRO & 29 \\
\hline 23 & 26-29.09.2011 & $\mathrm{MHI}+\mathrm{SSC}$ & 108 \\
\hline 24 & 10.09 .2011 & MHI & 40 \\
\hline 25 & $15-17.05 .2012$ & MHI & 56 \\
\hline 26 & 25-27.09.2012 & MHI & 78 \\
\hline 27 & 08.08 .2013 & MHI & 45 \\
\hline 28 & 25-27.10.2013 & MHI & 88 \\
\hline 29 & 05-06.06.2014 & $\mathrm{MHI}+\mathrm{SOI}$ & 63 \\
\hline 30 & $24-25.06 .2014$ & MHI + SOI & 63 \\
\hline 31 & 05-07.07.2014 & $\mathrm{MHI}+\mathrm{SOI}$ & 63 \\
\hline \multicolumn{4}{|c|}{ Total: } \\
\hline
\end{tabular}


Sampling of the empirical data used in the present paper included 1,443 stations implemented during 31 expeditions (see Table) in the Kerch Strait and the pre-strait areas of the Azov and Black Seas for June 2001 - July 2014 period. The range of depths studied was $0.5-50 \mathrm{~m}$.

All the soundings were performed with the depth step of $0.1 \mathrm{~m}$. Interpretation of the TSM content field structure was carried out using information on the DOM concentration, dynamics and thermohaline water structure.

The DOM content field in the Kerch port water area was considered according to the YugNIRO micro survey data. The concentration of this substance was determined by filtration and subsequent weighing of the dry matter.

Discussion of the results. TSM sources. As it is shown in $[5,7,8]$, the main anthropogenic TSM sources are located in the Kerch Strait water area, its pre-strait areas and in the Sea of Azov. In the strait waters, the TSM of artificial origin comes from various sources: with industrial effluents of enterprises, terminals and ports located on its shores; with Kerch sewage drainage; with discharges of contaminated rivers flowing into the strait (Melek-Chesme, Bulganak and Jarjava); as a result of advection of waters from the areas of active and closed landfills of soil recovered from dredging; from the road transshipment sites (Fig. 1). Shipping is an obvious source of pollutants although the unstudied one. Increased TSM content is typical for the Azov Sea waters entering the strait.

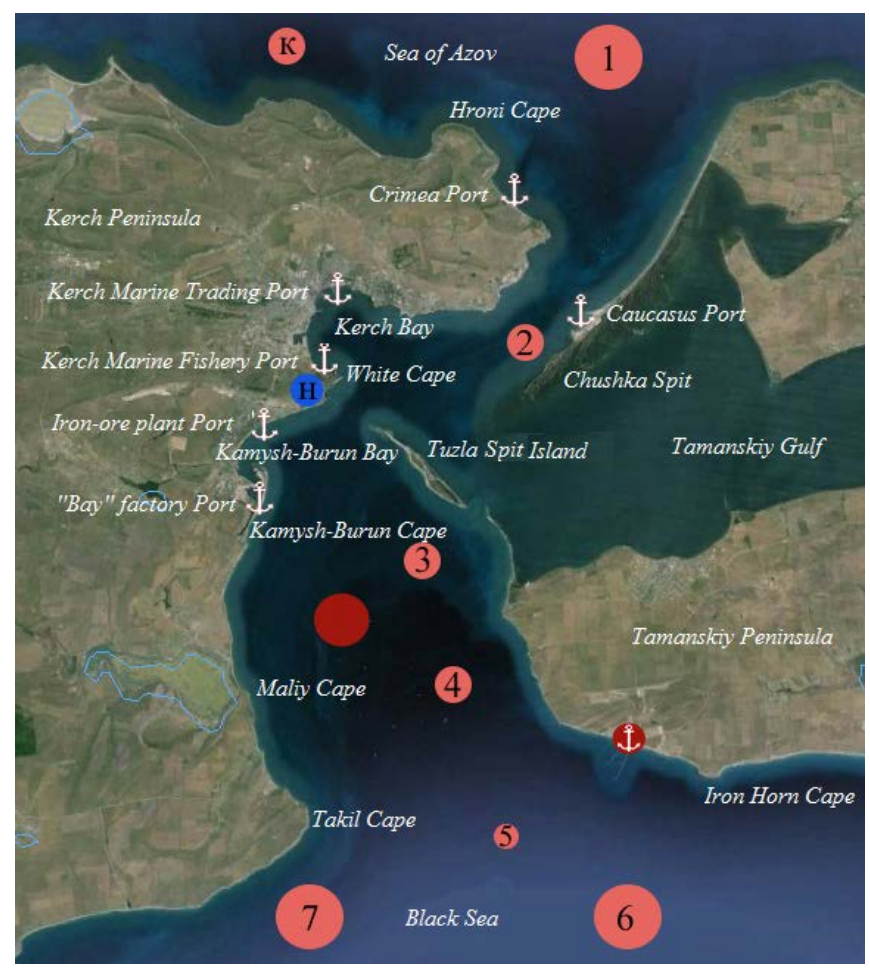

Fig. 1. The main physical and geographical landmarks and location of pollution sources on the satellite image of the Kerch Strait. Legend: closed landfills, 7 - active landfill; 
Sources of pollution deform the natural field structure of TSM concentration in a certain way. On the sites susceptible to anthropogenic impact, lenses with a maximum TSM content (4.5-36.4 mg/l, up to $260 \mathrm{mg} / \mathrm{l}$ during dredging) are formed in the suspended matter field. During calm sea, periods of gentle breezing and zonal wind, characterized by a slight acceleration, the lenses have distinct boundaries. Their particular horizontal and vertical scales range from hundreds of meters to several kilometers and $\sim 1$ to 3 meters, respectively.

The contamination sources with the same typical features deform the spatial structure of the natural field of the DOM content. In the predominant majority of cases, the maximum DOM content (of anthropogenic origin) of 4.5-18.1 mg/l was observed in the contaminated areas. That is, the detected sources contribute to contamination of the investigated water area with both by a toxic suspended and dissolved organic matters of artificial origin.

Particular practical significance of knowledge about TSM and DOM content sources and fields is that the waters contaminated by them do not manifest in the thermohaline structure, as well as in traditional complex fields of commonly observed hydrochemical elements. These substances can be detected only if there is information about the fields of suspended matter and dissolved organics.

Based on the qualitative analysis of the TSM content fields, its sources of anthropogenic origin in terms of their significance (productivity) can be represented in the following sequence: dredging; soil dumps; shipping; ports, road transshipment sites, terminals, Kerch sewage drainage; the Azov Sea waters; rivers flowing into the strait and flowing through the Kerch territory, polluted with industrial wastes. Below is a brief description of each source is given.

According to [9-11], the most significant TSM source of anthropogenic origin in the Kerch Strait waters is associated with dredging and subsequent dumping of seized soil.

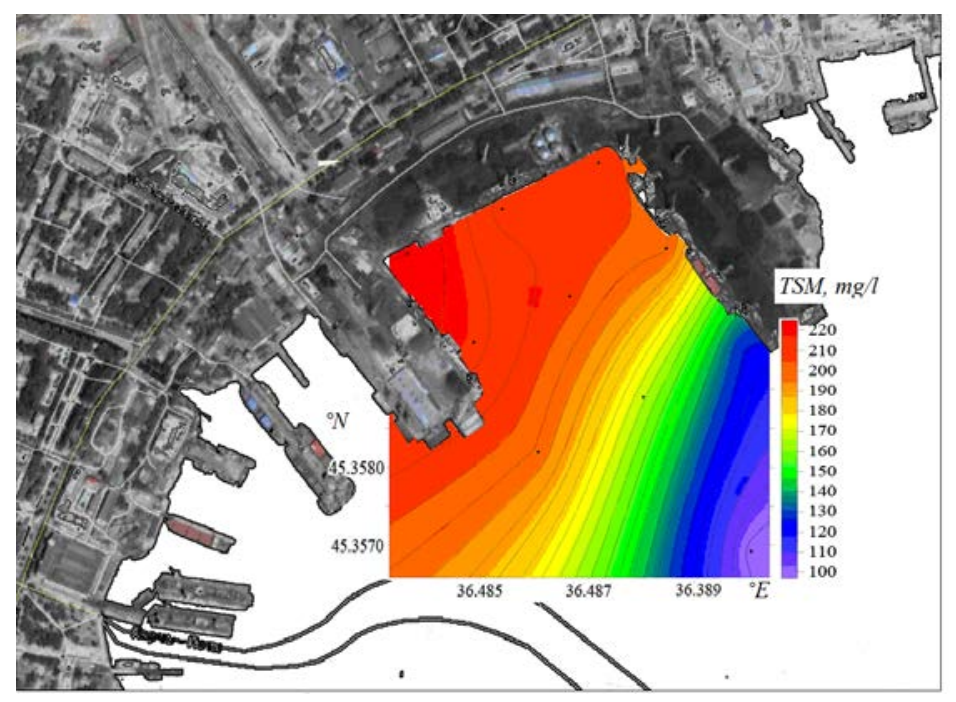

Fig. 2. TSM concentration distribution of in the near-bottom layer of the Kerch Sea Commercial Port water area during bottom dredging on June 13, 2000 
High productivity degree of these TSM sources related to dredging is presented in Fig. 2. It shows the result of an environmental micro-survey in the Kerch Commercial Sea Port, aimed at studying the multi-bucket dredger impact on the fields of the most important elements of aquatic environment ecological complex.

Particularly, as a result of the TSM concentration field analysis, it was found that the work of the dredger was accompanied by the substance content increase (hundreds of times higher than the surrounding background) in the entire water column (port depth is $\sim 7 \mathrm{~m}$ ). At the bottom layer of the port area the TSM content reached $260 \mathrm{mg} / \mathrm{l}$. There was practically no vertical stratification of suspended matter observed, the entire water column was saturated with it. A bright brown spot of turbulent waters formed on the adjacent water area of the Kerch Bay. It was visually different on the surface and had a distinct external boundary. The suspended matter concentration at the outer edge of this lens of turbid waters was abruptly reducing to several units (Fig. 2).

At present, the main dredging facilities in the Kerch Strait include the water area of the Kerch Sea Commercial Port and the navigable channel approaching it, as well as the Pavlovskoe and Chushkinskoe knees of the principal navigable Kerch-Yenikalskiy Channel. In some years dredging works were carried out in an approach channel to the Kerch Sea Fishing Port and in the water area of the port of the Kerch Iron Ore Combine [5, 7-11].

According to the data at our disposal, there are seven dumping zones in the Kerch Strait and in the pre-strait waters of the both seas (Fig. 1): an active waste deposit located in the Black Sea pre-strait area, in the vicinity of Takil Cape (landfill 7); four closed landfills in the southern part of the strait (landfills 3-6); a closed dumping zone in the Azov Sea pre-strait area, located a mile to the north-east of Chroni Cape (waste deposit 1). It is unknown whether a dumping zone in the coastal area of the Chushka Spit, to the south of the Port Kavkaz is under operation (landfill 2).

During the analyzed complex experimental research of the Kerch Strait in the area of each dumping zone, without exception, the local TSM content maxima (which were several times higher than the surrounding background), as well as other pollutants, were found. In particular, it has been shown [5, 7-11] that in the waters localized over the landfills, the organic contaminants (excessive DOM content) are monitored. This feature allows to state that each of the dumping zones in the strait (both closed and active landfills) is a source of total suspended and dissolved organic matters of anthropogenic origin.

Constant presence of excessive suspended matter in the dumping zones, as well as in beds of the navigable channels, can be explained by the low density of the upper soil layer in these areas [7, 12]. The process of bottom layer sediment spreading here by currents and waves is more intensive. The excessive organics entering the dumping zones is sorbed by the suspended matter and settles to the bottom, forming entrapped waters. Therefore, the landfills are centers of environmental hazard, where the suffocation phenomena development is very presumable.

One of the unstudied powerful anthropogenic sources of TSM in the Kerch Strait waters is due to navigation. The Kerch-Yenikalskiy navigable channel was designed on the assumption that it will be operated by river-sea type vessels with a displacement of not more than 5,000 tons. Currently, the intensity of navigation in the 
strait has increased tens of times. Large-tonnage deep-sea vessels with a displacement of over 50-80 thousand tons pass through the main and approach channels, roiling their bottom layer and edges by the propellers. According to visual assessments, the wake of such vessels is distinguished by a high turbidity on the surrounding background. It contains algae, grass, pieces of soil and polyethylene. At the bottom of the channels, a high content of TSM and DOM is constantly observed.

Anthropogenic sources related to ports, road transshipment sites, terminals, Kerch sewage drainage, the Azov Sea waters and rivers flowing into the strait (Fig. 1) and their manifestation in the TSM field are described in details in [5, 7-11].

In all the surveys without exception, a lens with a high content of TSM and DOM was fixed in the area of the Pavlovskaya Narrowness and in the southern part of the Kerch Bay. The source of pollution in this area turned out to be the oil terminal located on White Cape (Fig. 1, 3).

Another, more extensive, lens with approximately the same concentration of studied substances, discovered on May 5, 2005 in the northeastern part of the Kerch Bay (Fig. 3), had advective origin. Satellite data analysis [7] showed that this lens of contaminated waters of low salinity with a high concentration of TSM, DOM and petroleum products is not associated with coastal sources located in the Kerch Strait, but was taken from the Azov Sea. This fact testifies to the significant role of the Azov Sea as a source supplying anthropogenic suspended and dissolved organic matters to the Kerch Strait, and also confirms the opinion [4, 7] on the quality of the Azov Sea waters containing a wide range and high concentration of pollutants.
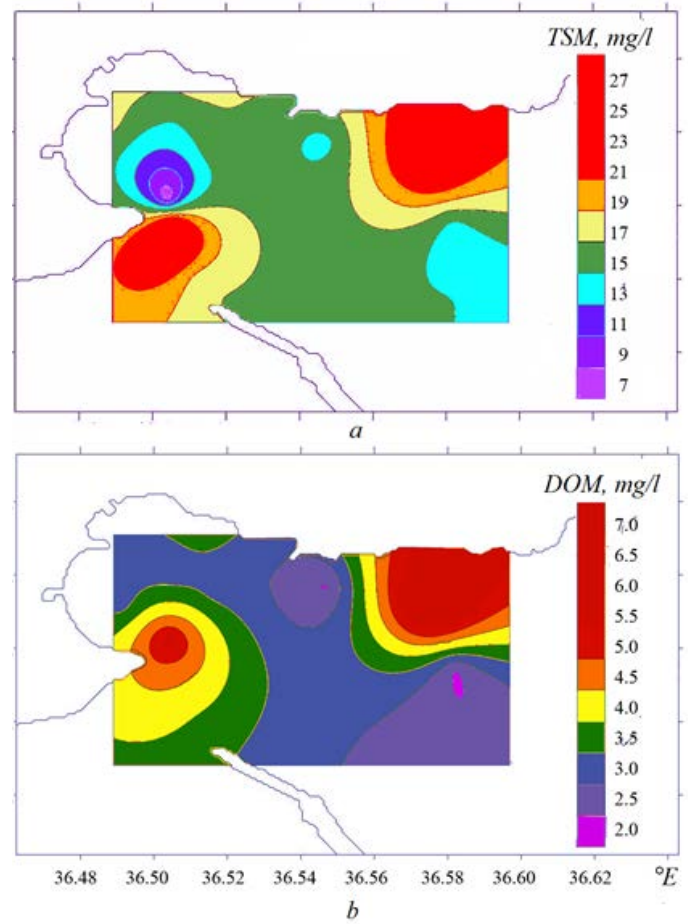

Fig. 3. TSM (a) and DOM (b) concentration distribution on $3 \mathrm{~m}$ horizon in the Kerch Bay on May 5, 2005

PHYSICAL OCEANOGRAPHY ISS. 6 (2017) 
Under a meridional wind, having a significant acceleration, the suspended matter of anthropogenic origin from local sources, carried by wind currents, extends to the extensive Kerch Strait water areas (miles and tens of miles) [5]. Getting into the Black Sea Rim Current eddies, it can reach the shores of Feodosiya and Anapa [7, 13].

Sandy beaches, shallows and spits of the strait can also be considered as the main natural DOM sources. The most significant of these are areas with a depth of less than $2 \mathrm{~m}$ on the western coast of the Chushka Spit, a shallow shelf between its southern extremity and Tuzla Island, the spits of the western and eastern extremities of Tuzla Island. These areas are well distinguished in satellite imagery [7, 14] by the increased turbidity. On the basis of contact optical measurements, it was found that the TSM content here is several times and an order of magnitude higher than the corresponding background concentrations in remote water areas (Fig. 4). The maximum recorded TSM concentration in the area of its natural sources reached $10-22 \mathrm{mg} / \mathrm{l}$.

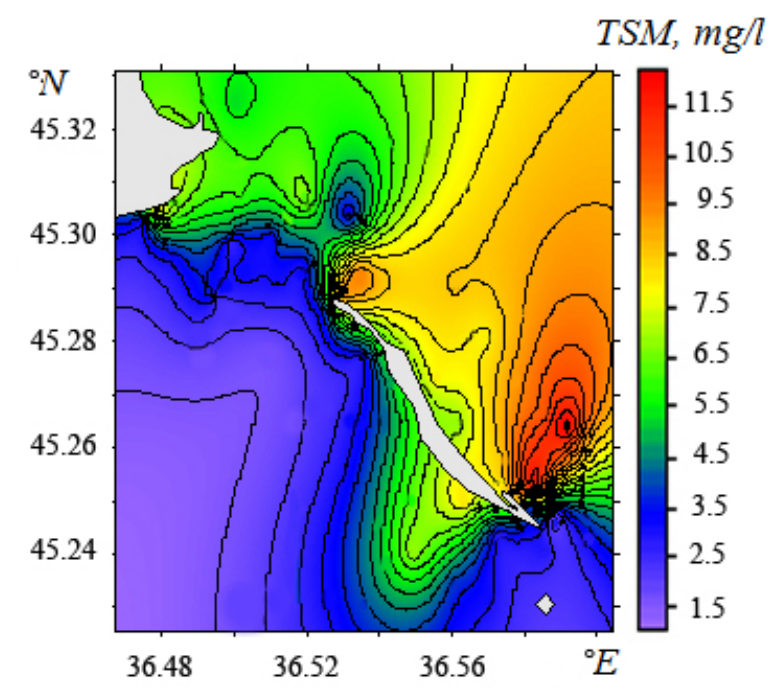

Fig. 4. TSM concentration distribution in the near-bottom water layer in the area of Tuzla Island under moderate south wind according to the results of the survey on July 24, 2008

In accordance to YugNIRO data [7], in the shallow area, located between the southern extremity of the Chushka Spit and Tuzla Island, on December 9, 2003, a day after the storm north-west wind, the TSM concentration in the upper water layer reached $70-80 \mathrm{mg} / \mathrm{l}$.

An important difference in the aquatic environment condition in areas with high TSM content due to natural sources is low (natural, 1.0 to $3.5 \mathrm{mg} / \mathrm{l}$ ) DOM concentrations. Then, as shown above, in the waters exposed to anthropogenic impact, the DOM content is significantly higher than the natural one.

TSM concentration field structure. Analyzing the horizontal structure of the TSM content field in the Kerch Strait on the basis of oceanographic surveys, the following typical feature was found. In the field of this magnitude, there is a sufficiently marked front, coinciding with the main thermohaline frontal section that 
delimits the Azov and Black Sea waters interacting in the strait. That is, the Azov and Black Sea waters penetrating the strait, in addition to the known thermohaline features, have their own TSM concentration. Moreover, it is much higher in the Azov Sea waters than in the Black Sea ones.

As an example, Fig. 5 shows the distribution of temperature, salinity and TSM content on the surface of the Kerch Strait waters, according to the data of the MHI expedition on July 10, 2010. It can be seen that in the fields of these parameters of environment (according to criterion of the maximum horizontal gradient [15]), the frontal section from the west to the northeast is well marked. Its bulk is located in the southern part of the strait. The front divided the warmer $\left(25.7-26.1^{\circ} \mathrm{C}\right)$ less saline (11.5-13.0 PSU) and more TSM saturated (3.2-4.7 mg/l) Azov Sea waters from the relatively cool $\left(24.7-25.0^{\circ} \mathrm{C}\right)$ more saline (16.0-18.0 PSU) and less TSM saturated (1.0-2.2 mg/l) Black Sea waters.
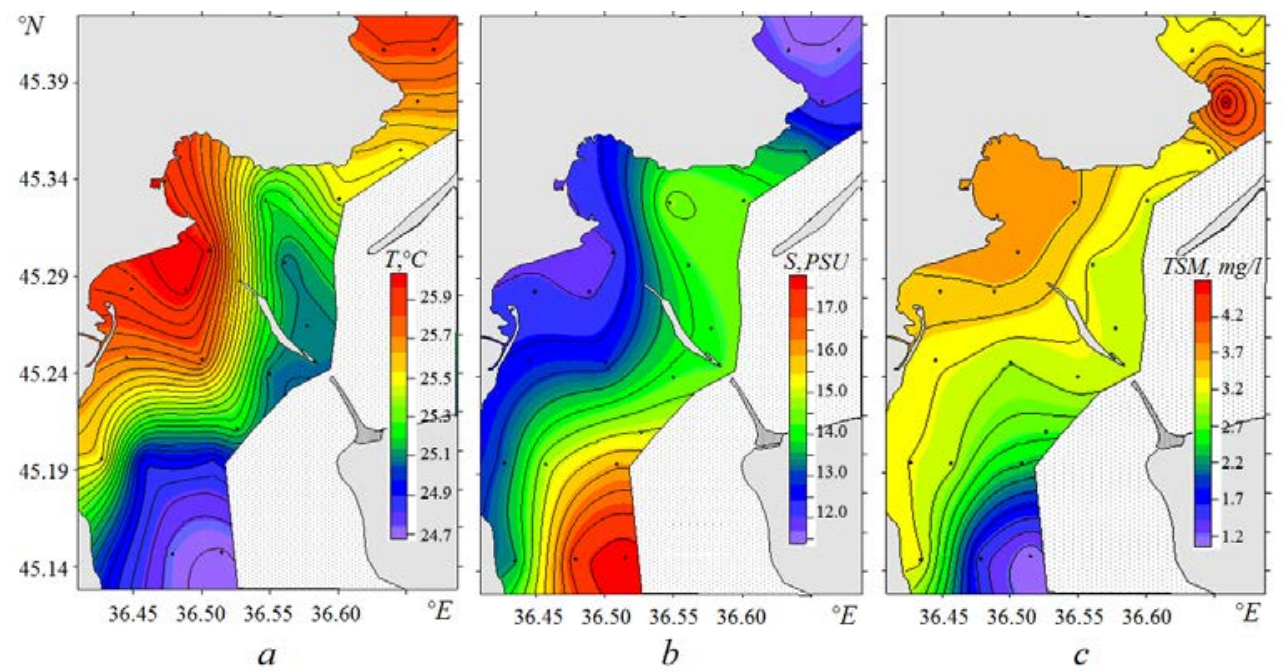

Fig. 5. Distribution of temperature $(a)$, salinity $(b)$ and TSM content $(c)$ on the surface of the Kerch Strait waters on July 10, 2010

The elementary statistical assessments in Fig. 6 show that the situation discussed above is not accidental and that in the uncontaminated Kerch Strait waters the frontal section in the TSM field is a typical large-scale (within the studied region) element of the water structure. To prove this property, it was necessary to determine the characteristic TSM concentration in the uncontaminated Azov and Black Sea waters, located respectively to the north and south relative to the main thermohaline front.

Based on the analysis of the available information, it is revealed that in the thermohaline field the main frontal section of the Kerch Strait is inclined toward the Black Sea and has a width of about three miles. It is located between 12 and 16 PSU isohalines both on the surface and at the bottom.

According to the salinity criteria $\mathrm{S}<12$ PSU (the Azov Sea waters), $\mathrm{S}>16$ PSU (the Black Sea waters), two sampling probes with TSM content fixation on the surface were formed. Then, high values (more than $4.5 \mathrm{mg} / \mathrm{l}$ ) due to anthropogenic and natural sources of this substance were filtered from each sample PHYSICAL OCEANOGRAPHY ISS. 6 (2017) 
of TSM concentration. Two histograms of the TSM concentration repeatability in uncontaminated Azov and Black Sea waters interacting in the Kerch Strait (Fig. 6) were calculated from the two remaining samples.

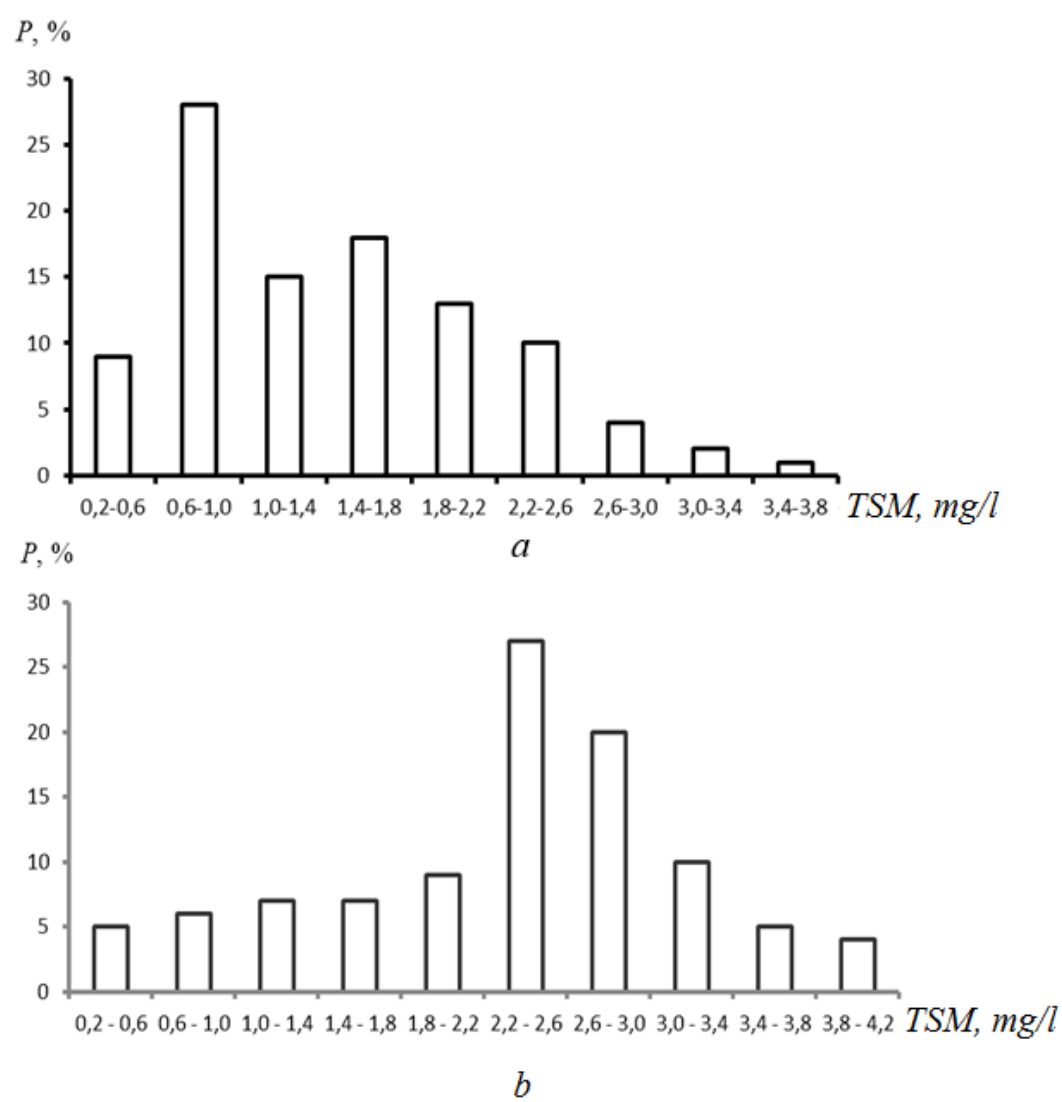

Fig. 6. Histograms of the TSM concentration repeatability for uncontaminated Black Sea $(a)$ and Azov Sea $(b)$ waters

As a result, it turned out that on the surface in uncontaminated Black Sea waters the TSM content varied within the limits of $0.2-3.8 \mathrm{mg} / \mathrm{l}$; most often, with $28 \%$ repeatability, values in the range of 0.6 to $1.0 \mathrm{mg} / \mathrm{l}$ were found (Fig. 6, $a$ ). Therefore, as a criteria for distinguishing surface waters of the Black Sea origin that do not contain TSM anthropogenic additive in the Kerch Strait, the concentration of this substance can be taken as $0.8 \mathrm{mg} / \mathrm{l}$.

In the uncontaminated Azov Sea waters, the TSM content varied from 0.1 to $4.3 \mathrm{mg} / \mathrm{l}$; most often, with $27 \%$ repeatability, here the values in the range of 2.2-2.6 mg/l were observed (Fig. 6, b). Therefore, as an indicator of the natural norm of the TSM content in the Azov Sea waters entering the strait, its concentration on the surface may be assumed to be $\sim 2.4 \mathrm{mg} / \mathrm{l}$.

It should be noted that sources of anthropogenic origin suspended matter noticeably deform the structure of the natural field of TSM concentration in the Kerch Strait and, accordingly, its frontal section. Depending on pollution degree of the strait waters, which practically do not affect the thermohaline field, the frontal sec- 
tion in the TSM concentration field is not always sufficiently marked. It changes its shape, shifts relative to the thermohaline front and sometimes changes the sign of the horizontal gradient.

Vertical structure of the TSM content field of the Azov and Black Sea waters interacting in the Kerch Strait has qualitatively different characteristics. The waters of the Sea of Azov, which are not exposed to anthropogenic impact, are characterized by a non-monotonic distribution of the TSM(z) concentration. Suspended matter flow, carried from the Sea of Azov, differs by heterogeneity. It contains separate, suspended matter saturated lenses alternating with water lenses with an extremely low TSM content (Fig. 7, $a$ ).

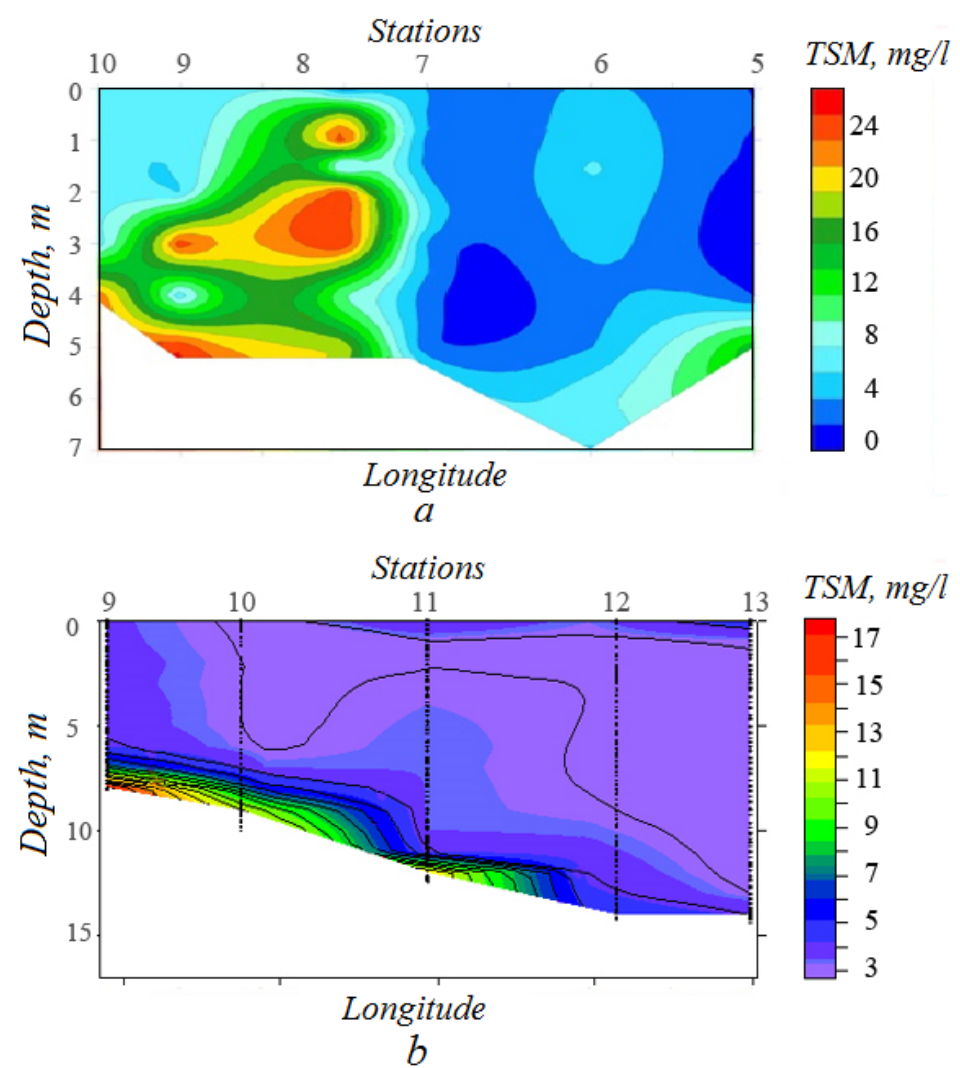

Fig. 7. Typical distribution of TSM concentration in zonal sections in the pre-strait zones of the Azov (a) and Black (b) Seas

Uncontaminated waters of the Black Sea are uniform vertically. Here the $\operatorname{TSM}(z)$ concentration is an insignificantly increasing function of depth, which increases abruptly in the thin near-bottom layer (Fig. $7, b$ ). Regardless of the origin of the strait waters, the absolute maximum of the TSM concentration is usually observed at the bottom. This effect is especially marked in the navigable canals.

The revealed regularities of structure and numerical parameters of the TSM concentration field in the Kerch Strait are in good agreement with the concepts of water transparency - the inverse function of the suspended matter content. It is known $[4,7]$ that in the Kerch Strait the Azov Sea waters have small transparency, 
equal to several decimeters, while the transparency of the Black Sea waters is higher by about an order of magnitude.

Conclusion. Based on result of a series of expeditions carried out in 2001-2014, the notions on the sources and structure of the total suspended matter concentration field in the Kerch Strait waters were obtained.

It is shown that the main anthropogenic sources of TSM are related to the operation of ports located on the strait coasts and in the Azov Sea, industrial enterprises, with sewage collectors, cargo terminals, road transshipment sites and landfills.

Pollution sources deform the structure of the natural field of the TSM concentration. In areas exposed to anthropogenic impact, lenses with a maximum TSM content of 4.5 to $36.4 \mathrm{mg} / \mathrm{l}$ are formed in the field of the considered parameter of environment, for which a high concentration of DOM is also typical. Their characteristic horizontal and vertical scales range from hundreds of meters to several kilometers and $\sim 1$ to 3 meters, respectively.

In the Kerch Strait, a frontal section is found in the TSM concentration field, which coincides with the main thermohaline front, separating the Azov and Black Sea waters interacting in the strait. Depending on the degree of the strait water pollution, which practically does not affect the thermohaline field, the front section in the TSM content field is not always sufficiently marked. It changes shape, shifts relative to the thermohaline front and sometimes changes the sign of the horizontal gradient.

The Azov and Black Sea waters penetrating in the strait, in addition to the known thermohaline features have their own TSM concentration. In the uncontaminated Azov Sea waters, the most common concentration of this substance is $2.4 \mathrm{mg} / \mathrm{l}$, in uncontaminated Black Sea ones $-0.8 \mathrm{mg} / \mathrm{l}$.

It was found that the waters interacting in the strait have qualitatively different signs of vertical stratification of the TSM concentration field. The Azov Sea waters, which are not exposed to anthropogenic impact, are characterized by a nonmonotonic distribution of the $\operatorname{TSM}(z)$ concentration. The suspended matter flows from the Azov Sea contain suspended matter saturated lenses, which alternate with lenses of waters with a low TSM content. Uncontaminated Black Sea waters are uniform vertically. Here the $\operatorname{TSM}(z)$ concentration is an insignificantly increasing function of depth, which increases abruptly in the thin bottom layer.

Acknowledgements. The work was fulfilled within the framework of the State Order No. 0827-2014-0010 Complex Interdisciplinary Research of the Oceanological Processes Determine the Functioning and Evolution of the Ecosystems of the Black and Azov Seas, based on Modern Methods for Marine Environment State and Grid Technologies (Fundamental Oceanology code).

\section{REFERENCES}

1. Aibulatov, N.A. and Novikova, Z.T., 1984. Kolichestvennoe Raspredelenie Vzvesi v Shel'fovyh Vodah Chernogo Morya [Quantitative Suspended Matter Distribution in the Shelf Waters of the Black Sea]. Oceanology, XXIY (6), pp. 960-968 (in Russian).

2. Aibulatov, N.A., 1990. Dinamika Tverdogo Veshhestva $v$ Shel'fovoy Zone [Dynamics of Solids in the Shelf Zone]. Leningrad: Gidrometeoizdat, 270 p. (in Russian). 
3. Trimonis, Je.S. and Shimkus, K.M., 1976. Kolichestvennoe Raspredelenie Vzvesi v Chernom More [Quantitative Distribution of Suspended Matter in the Black Sea]. Oceanology, XYI (4), pp. 648-654 (in Russian).

4. Lisitsyn, A.P., 1982. Lavinnaya Sedimentatsiya v Okeane [Avalanche Sedimentation in the Ocean]. Rostov-on-Don: Rostov University Publ., 1982. pp. 95-118 (in Russian).

5. Lomakin, P.D., Spiridonova, E.O., Chepyzhenko, A.I. and Chepyzhenko, A.A., 2008. Antropogennye i Prirodnye Istochniki Vzveshennogo Veshhestva v Vodah Kerchenskogo Proliva [Anthropogenic and Natural Sources of Total Suspended Matter in the Kerch Strait Waters]. Morskoy Ekologicheskiy Zhurnal, 7(4), pp. 51-59 (in Russian).

6. HYDROoptics Ltd, 2012. Kompleks Gidrobiofizicheskij Mul'tiparametricheskij Pogruzhnoj Avtonomnyj «KONDOR» [Hydrobiophysical Multiparameter Sinking Autonomous Complex "KONDOR"]. Available at: http://ecodevice.com.ua/ecodevice-catalogue/multiturbidimeterkondor [Accessed: 4 May 2017] (in Russian).

7. Lomakin, P.D. and Spiridonova, E.O., 2010. Prirodnye i Antropogennye Izmeneniya v Polyah Vazhnejshih Abioticheskih Elementov Ekologicheskogo Kompleksa Kerchenskogo Proliva $v$ Techenie Dvuh Poslednih Desyatiletiy [Natural and Anthropogenic Changes in the Fields of the Most Important Abiotic Elements of the Kerch Strait Ecological Complex During the Last Two Decades]. Sevastopol: ECOSI-Gidrofizika, 118 p. (in Russian).

8. Sapozhnikov, V.V., Kumantsov, M.I., Agatova, A.I., Arzhanova, N.V., Lapina, N.M., Roi, V.I., Stolyarskii, S.I., Bondarenko, L.G. and Panov, B.N. [et al.], 2011. Complex Investigations of the Kerch Strait. Okeanology, [e-journal] 51(5), pp. 896-898. doi:10.1134/S0001437011050146

9. Volovik, S.P., Rogov, S.F. and Shishkin, V.V., 1973. Migracii Hamsy i Drugih Ryb Cherez Kerchenskiy Proliv i Trebovaniya Rybnogo Hozyaystva k Konstrukcii i Rezhimu Ekspluatacii Reguliruyuchshego Gidrouzla [About Anchovy and Other Fish Migrations through the Kerch Strait and the Fishing Industry Requirements for Regulatory Hydroelectric Complex Design and Operation Regime]. Rostov-on-Don, 34 p. (in Russian).

10. Brjancev, V.A., 1989. Razrabotka Nauchnyh Osnov Dlya Otsenki Vliyaniya Dampinga Gruntov na Ekosistemu Kerchenskogo Predproliv'ya i Prilegayushhey Zony [Scientific Foundations Development for Assessing the Impact of Soil Dumping on the Kerch Strait and the Adjacent Zone Ecosystem]. Kerch, 89 p. (in Russian).

11. Petrenko, O.A., Sebah, L.K. and Pankratova, T.M., 1998. Antropogennye Izmeneniya Morskoy Sredy pod Vozdeystviem Dampinga Gruntov Dnouglubleniya v Kerchenskoy Predprolivnoy Zone Chernogo Morya [Anthropogenic Changes in Marine Environment under the Influence of the Dredging Soil Dumping in the Kerch Pre-strait Zone of the Black Sea]. In: Trudy JugNIRO [Proc. of JugNIRO]. Vol. 44, pp. 83-88 (in Russian).

12. Khrustalev, Yu.P., Denisov, V.I., 2001. Features of Distribution of Suspended Matter and Intensity of Its Sedimentation in the Kerch Strait Region of the Black Sea. Oceanology, 41(6), pp. 907-916.

13. Petrenko, O.A., Sebakh, L.K., Fashchuk, D.Ya., 2002. Some Environmental Consequences of Soil Dumping in the Black Sea as a Result of Dredging Operations in Kerch Strait. Water Resources, [e-journal] 29(5), pp. 573-586. doi:10.1023/A:1020338201171

14. Shuisky, Y.D., 1993. Regularities of the Abrasive Coast Development of the Ukrainian Black Sea. In: R.D. Kos'yan, O.T. Magoon, eds., 1993. Coastlines of the Black Sea. New York: American Soc. Civil Engs. Publ., pp. 406-421.

15. Fedorov, K.N., 1983. Fizicheskaya Priroda i Struktura Okeanicheskih Frontov [The Oceanic Fronts Physical Nature and Structure]. Leningrad: Gidrometeoizdat, 296 p. (in Russian). 